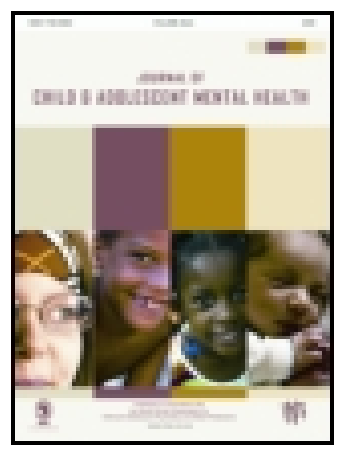

\title{
Transformation through Occupation
}

\author{
Lisa Wegner
}

To cite this article: Lisa Wegner (2004) Transformation through Occupation, , 16:2, 135-136, DOI: 10.2989/17280580409486584

To link to this article: https://doi.org/10.2989/17280580409486584

曲 Published online: 12 Nov 2009.

Submit your article to this journal

Џll Article views: 149

Q View related articles $\sqsubset$

4 Citing articles: 1 View citing articles 지 
Book Review

\title{
Transformation through Occupation
}

\author{
Ruth Watson and Leslie Swartz (eds) \\ Whurr Publishers Ltd, 19b Compton Terrace, London N1 2UN, United Kingdom (2004) \\ Paperback ISBN 1861564252 (£25.00) \\ 400 pages \\ e-mail: info@whurr.co.uk,www.whurr.co.uk
}

Working in the context of a developing country such as South Africa provides a multitude of challenges for professionals in all fields. The last few years since democratisation have seen a transformation in the way occupational therapy is being practiced in South Africa, as the profession redefines itself to meet the needs of the people. The book "Transformation through Occupation" provides an outlet for the voice of South African occupational therapists to be heard, and showcases occupational therapy intervention with groups, communities and populations characterised by poverty, disadvantage and social problems. This book makes a unique contribution to occupational therapy because it provides a direction for transformation and development of the profession on a global level. The meaning of occupation, occupational justice and occupational development within different contexts and populations is explored indepth through the use of thought-provoking discussions, case studies and narrative story-telling of therapists' experiences. "Transformation through Occupation" has been written by clinicians, academic educators and researchers from the fields of occupational therapy and psychology. The authors present their experiences of moving beyond the traditional realms of occupational therapy practice in response to the demands of working in a post-apartheid South Africa.

The first part of the book introduces the main themes and positions the book in relation to occupation, service delivery and contextual influences. Four leading occupational therapists from around the world were asked the question "Is occupational therapy ready to move forward and make occupation a political issue, thus ensuring that occupational risks are addressed as social development issues and not only as a health concern?" ( 110$)$. Their responses indicate that, globally, the profession is moving towards redefining itself in terms of social development based on occupation. Global and African issues and policies that impact on occupational therapy are reviewed. Social and cultural values such as the concept of interdependence (as an African way of thinking) $v s$ independence and their influence on occupation and choice are discussed. The first part of the book ends with a chapter which poses the challenging question of how the profession can use occupation to bring about transformation to enrich and redirect peoples' lives, within groups, commu- nities and populations.

The second and third parts of the book illustrate the transformative powers of occupation in action, and show the opportunities for occupational therapy practice in environments beyond traditional health settings. Part 2 provides examples of practice highlighting the adaptation of the profession to meet the environmental demands of the South African context, and Part 3 examines service implications. The occupational issues and dilemmas that people living in poverty have to endure are presented. Case studies include poor disabled women, a self-help group of mothers with disabled children living in a poverty-stricken area, children attending a mainstream school in a deprived community, homeless men, and disabled people living in rural areas. Empowerment and community development are key issues that emerge throughout these chapters. Much of the work occurs in groups providing an opportunity to highlight the use of occupation within group settings.

The impact of HIVIAIDS on occupation and the role of occupational therapy is a topic that the profession needs to address in more depth. This book devotes three chapters to HIVIAIDS, dealing with the impact of HIVIAIDS on the occupation of fathering, the role of context in influencing play in poor socio-economic conditions with regard to mothers of children with HIVIAIDS, and the experiences of grandmothers affected by HIVIAIDS. Occupational therapy is shown to be a "facilitator of engagement in the process of occupational adaptation" ( $p 126)$, illustrating how people can learn to cope with their situation through engagement in various occupations, and revealing more about how occupational therapy can contribute to community development.

Other chapters deal with occupational therapy services within the criminal justice system, where the interface between enabling occupation and occupational justice applied to women and young offenders based on a population approach is presented. Recognition is given to the value of work in the promotion of wellness of people with psychiatric illness. There is a thought-provoking, moving discussion of the role and dimensions of spirituality in two vastly differing contexts as two therapists describe their experiences of how spirituality manifests in their interactions with clients in a private hand clinic, and with poor women who 
were HIV-positive in a community setting.

The final part of the book addresses the challenge of transformation and presents a model for transformation through occupation which will complement existing occupational therapy practice. In her foreword, Betty Hasselkus calls the book "a gift to the profession of occupational therapy" and indeed it is, because this book will challenge and provoke occupational therapists across the world to look beyond traditional models of individually-focussed curative and preventive practice in clinical settings towards health promotion with groups, communities and populations. It is a catalyst to stimulate discussion and ideas and is therefore an important read for therapists across the world. This book will enable occupational therapists to broaden their thinking around the powers of occupation, and clinicians working in similar situations as those described in the book will be able to find ways of dealing with the problems facing them. Educators will have ample scope for extracting issues and themes for discussion with under- and postgraduate students, with plenty of case studies to bring different issues to life. Theorists and researchers will be able to build on the debates to further develop the scope of the profession. Finally, the book will have broader appeal to anyone who is interested in exploring new and innovative ways for promoting health, wellness and community development, particularly amongst marginalised people.

\author{
Lisa Wegner \\ Department of Occupational Therapy, University of the Western Cape, Private Bag X17, Bellville 7535, Cape Town, South \\ Africa \\ e-mail: Iwegner@uwc.ac.za
}

